\title{
Analisis strategi dan klasterisasi ketahanan pangan nasional dalam menghadapi pandemi covid-19
}

Strategy analysis and clusterization of national food security in facing the covid-19
pandemic

\author{
Audi Ramadhan ${ }^{1)^{*}}$, Kinanti Prawita ${ }^{1)}$, M. Andik Izzudin ${ }^{1)}$, Gitta Amandha ${ }^{2)}$ \\ ${ }^{1}$ Program Studi Sistem Informasi, Univeristas Islam Negeri Sunan Ampel Surabaya \\ ${ }^{2}$ Program Studi Agroteknologi, Universitas Bangka Belitung \\ *Email korespondensi: audiramadhan29@gmail.com
}

Informasi Artikel:

Dikirim: 27/07/2020; disetujui: 20/12/2020; diterbitkan: 30/03/2021

\begin{abstract}
The covid-19 outbreak that scours the world nowadays is affecting all sectors, including food security. Therefore it needs to restructure the food security policies to ensure that every people obtains adequate and nutritious food. However, the society in each province has different conditions. Thus the clusterization of food security level per province is indispensable to support strategic and policy decisions in order to face the Covid-19 pandemic. This research aimed to cluster the food security level of each province in Indonesia. Furthermore, this research also compares several clustering methods. The clustering method that used as a comparison in this study is K-means, DBSCAN, Louvain, and Self-organizing maps methods. The method with the highest silhouette coefficient value in this research will represent the results of food security clustering. The result of the research shows that $K$-means achieve the highest silhouette coefficient value (0.568). Therefore the clusterization result of $K$-means was chosen to represent the level of food security in this research. Further, it was followed by selforganizing maps with silhouette coefficient 0.559, Louvain 0.312, and DBSCAN 0.15. The clusterization result show there are 7 provinces with high food security index, 24 provinces with medium food security index, and 3 provinces with low food security index. This research also proposes policies strategy and recommendations related to regional food security conditions in order to face the Covid-19 pandemic. This research is expected to be a consideration of the Indonesian government in making policies on national food security.
\end{abstract}

Keywords: Food security, Clustering Method, Machine learning, Covid-19

\begin{abstract}
ABSTRAK
Wabah Covid-19 yang melanda dunia dewasa ini berdampak kepada semua sektor, termasuk ketahanan pangan. Sehingga perlu adanya restrukturisasi kebijakan ketahanan pangan untuk menjamin agar setiap masyarakat mendapatkan pangan yang cukup dan bergizi. Namun, masyarakat di setiap provinsi memiliki kondisi yang berbeda-beda. Dengan demikian klasterisasi tingkat ketahanan pangan per provinsi sangat diperlukan untuk menjadi pendukung keputusan strategi dan kebijakan dalam menghadapi pandemi Covid-19. Penelitian ini bertujuan untuk mengklasterisasi tingkat ketahanan pangan setiap provinsi di Indonesia. Selain itu penelitian ini juga membandingkan beberapa metode klasterisasi. Metode klasterisasi yang menjadi perbandingan dalam penelitian ini adalah metode K-means, DBSCAN, louvain dan self organizing maps. Metode dengan
\end{abstract}


nilai silhouette coefficient tertinggi pada penelitian ini akan merepresentasikan hasil klasterisasi ketahanan pangan. Hasil penelitian ini menunjukkan bahwa K-means memiliki nilai silhouette coefficient yang tertinggi $(0,568)$. Sehingga hasil klasterisasi dengan metode K-means dipilih untuk merepresentasikan tingkat ketahanan pangan pada penelitian ini. Selanjutnya diikuti dengan metode self organizing maps dengan nilai silhouette coefficient 0,559, metode louvain 0,312 dan metode DBSCAN 0,15. Hasil klasterisasi menunjukkan bahwa terdapat 7 provinsi dengan indeks ketahanan pangan tinggi, 24 provinsi dengan indeks ketahanan pangan sedang dan 3 provinsi dengan indeks ketahanan pangan rendah. Penelitian ini juga memberi strategi dan rekomendasi kebijakan terkait dengan kondisi ketahanan pangan regional dalam menghadapi pandemi Covid-19. Dengan adanya penelitian ini diharapkan dapat menjadi bahan pertimbangan pemerintahan Indonesia dalam mengambil kebijakan tentang ketahanan pangan nasional.

Kata kunci : Ketahanan Pangan, Metode Klasterisasi, Machine learning, Covid-19

\section{PENDAHULUAN}

Saat ini wabah Covid-19 telah menjadi pandemi membuat kekacauan di masyarakat karena dianggap sebagai ancaman berbahaya bagi manusia di abad ke-21. Pemerintah dituntut untuk preventif dalam mengamankan masyarakat yang tidak terinfeksi dan reaktif dalam menjaga stabilitas dan peningkatan jumlah korban dari Covid-19 dengan memobilisasi semua kapabilitas dan sumber daya yang ada. jika tidak, jumlah korban Covid-19 akan meledak dan berdampak pada kelangsungan umat manusia yang dimulai dari resesi, kelaparan hingga kematian karena pandemi. Hal ini menandakan pentingnya mitigasi dari dampak pandemi dan kolaborasi dari masyarakat dengan pemerintah untuk menyelesaikan permasalahan pandemi Covid-19 saat ini. Perancangan kebijakan yang tepat oleh pemerintah terkait dampak terhadap sektor-sektor tertentu dapat menjadi salah satu langkah awal yang dilakukan untuk meminimalisir risiko dari Covid-19. Selain di sektor kesehatan, salah satu dampak pandemi Covid-19 yang paling menonjol ialah pada sektor sosio-ekonomi (Nicola et al., 2020). Seiring dengan meningkatnya jumlah kasus Covid-19 di Indonesia, perputaran roda ekonomi turut berhenti dikarenakan adanya pembatasan aktivitas masyarakat dalam kehidupan sehari-hari. Hal ini menyebabkan adanya kepanikan di masyarakat yang membuat masyarakat melakukan panic buying yang bertujuan mengamankan stok pangan rumah tangga dalam satu waktu agar dapat mengurangi intensitas interaksi (Roy et al., 2020). Dengan adanya panic buying yang dilakukan masyarakat, risiko keterbatasan dan habisnya ketersediaan pangan yang beredar di masyarakat semakin meningkat. Selain itu, pembatasan sosial yang di implementasikan di setiap daerah juga menjadi hambatan untuk modal transportasi yang bertujuan untuk mendistribusikan stok pangan. Dengan demikian, ketersediaan pangan yang menjadi aspek ketahanan pangan nasional merupakan hal yang harus diperhatikan oleh pemerintah.

Ketahanan pangan dapat didefinisikan sebagai situasi atau kondisi dimana seluruh masyarakat dalam satu waktu secara fisik, sosial dan akses ekonomi untuk mendapatkan makanan yang cukup, aman dan bernutrisi yang bertujuan untuk memenuhi dan mempreferensi makanan untuk kehidupan yang aktif dan sehat (Food and Agriculture Organization, 2008; Schmidhuber dan Tubiello, 2007). Pengukuran ketahanan pangan nasional memiliki tiga pilar, yakni ketersediaan, akses dan pemanfaatan pangan (The Lancet, 2013). Ketiga pilar tersebut memiliki peran masingmasing dalam menentukan cluster ketahanan pangan, seperti aspek ketersediaan pangan yang mendefinisikan tentang kondisi tersedianya produksi, cadangan dan transaksi pangan, akses pangan yang mendefinisikan tentang kemampuan rumah tangga untuk mendapatkan pangan yang cukup dan bergizi 
serta aspek pemanfaatan pangan yang didefinisikan sebagai penyerapan zat gizi pangan oleh individu dan penggunaan pangan oleh rumah tangga (PinstrupAndersen, 2009). Di masa pandemi Covid-19 ini, kebijakan terkait dengan ketahanan pangan seperti konsumsi rumah tangga menjadi salah satu hal yang penting untuk menggerakkan kehidupan masyarakat serta roda perekonomian sehari-hari. Wabah Covid-19 ini dapat dikategorikan sebagai perubahan lingkungan, hal ini ditinjau dari virus-virus sejenis yang semakin bermutasi dan menyebabkan gejala-gejala yang baru jika menginfeksi tubuh manusia. Di samping itu, perubahan lingkungan dapat menyebabkan ketidakpastian stabilitas, produktivitas dan pendayagunaan pangan (Godfray dan Garnett, 2014). Hal tersebut menjadi tantangan di sektor ketahanan pangan mengingat jumlah penduduk dan urbanisasi di Indonesia semakin meningkat. Jika tidak dikelola dengan baik, ketahanan pangan akan berdampak pada kemiskinan dan kelaparan (Headey dan Martin, 2016). Selanjutnya, kedua dampak tersebut berkembang lebih lanjut seperti meningkatnya angka kriminalitas dan penjarahan (Lin, 2008). Dengan demikian, pengelolaan ketahanan pangan dapat berdampak sangat kompleks jika tidak dikelola dengan baik terutama di masa pandemi Covid-19 ini. Sehingga analisis awal untuk mengukur ketahanan pangan menjadi sangat penting. Dengan adanya analisis tersebut, pengambilan kebijakan terkait ketahanan pangan di setiap provinsi oleh pemerintah akan menjadi lebih mudah serta akurat jika dilakukan dengan pendekatan kecerdasan buatan.

Berdasarkan pada penelitian-penelitian sebelumnya, analisis ketahanan pangan hanya terbatas pada perhitungan pembobotan secara subjektif dan statistik tradisional serta jika menggunakan metode pembelajaran mesin, hanya terbatas pada satu metode. Terdapat penelitian sebelumnya yang menganalisis ketahanan pangan Indonesia menggunakan metode Multivariate Normal Based Clustering model (Rahayu,
Purwaningsih, \& Daerobi, 2019). Penelitian tersebut menghasilkan pemetaan hasil klasterisasi ketahanan pangan di setiap provinsi Indonesia. Selanjutnya terdapat penelitian tentang analisis ketahanan pangan provinsi di Indonesia dalam upaya menjaga stabilitas ketersediaan pangan dengan menggunakan metode K-Means (Sudirman, Windarto, dan Wanto, 2018). Penelitian tersebut terbatas pada jumlah indikator pengukuran yang menyebabkan adanya keterbatasan keluasan dan akurasi variabel. Selain itu juga terdapat penelitian terkait tentang klasterisasi efektifitas irigasi dan dampaknya terhadap ketahanan pangan yang dipengaruhi oleh beberapa variabel lain seperti pendapatan dan tingkat konsumsi pangan (Adeniyi dan Dinbabo, 2020). Penelitian tersebut mengintegrasikan beberapa metode dalam model analisisnya seperti korelasi pearson, metode klasterisasi hirarki dan regresi multinominal. Sehingga distingsi dari penelitian ini adalah dengan adanya perbedaan metode yang lebih modern dalam menganalisis ketahanan pangan dan membahas tentang dampak pandemi Covid19 terhadap ketahanan pangan nasional serta langkah dalam memitigasi hal tersebut. Penelitian ini bertujuan untuk mengklasterisasi ketahanan pangan setiap provinsi yang ada di Indonesia dalam menghadapi Covid-19. Selain itu, Dengan adanya perkembangan teknologi analisis data seperti pembelajaran mesin, pekerjaan manusia dalam menganalisis menjadi lebih mudah, salah satunya dapat diterapkan pada sektor ketahanan pangan (King et al., 2017). Sehingga penelitian ini juga bertujuan untuk membandingkan beberapa metode klasterisasi seperti k-means, DBSCAN, Louvain Clustering dan Self Organizing Maps. Hasil klasteriasi metode dengan nilai koefisien silhouette tertinggi akan menjadi patokan dalam merepresentasikan ketahanan pangan nasional. Hal ini bertujuan agar mendapatkan hasil klasterisasi yang maksimal dan akurat. Langkah-langkah dari penelitian ini terdiri dari pengumpulan data, pembersihan data, penskalaan fitur atau normalisasi hingga pemodelan metode. 
Dengan adanya penelitian ini diharapkan dapat menjadi bahan pertimbangan pemerintah dalam menentukan kebijakan lebih lanjut terkait dengan konsumsi rumah tangga sehari-hari di masa pandemi Covid-19.

\section{METODE}

Penelitian ini menggunakan data sekunder dengan mengacu pada data Indeks Ketahanan Pangan Nasional Indonesia (IKP) tahun 2019 yang dikeluarkan oleh Badan Ketahanan Pangan Kementrian Pertanian Indonesia. Penelitian ini menggunakan metode pengelompokan dengan clustering untuk memetakan 34 provinsi di Indonesia dengan status ketahanan pangan dalam menghadapi pandemi Covid 19 yang melanda Indonesia pada tahun 2020. Informasi mengenai ketahanan pangan yang akurat, berkala, komprehensif dan tertata sangat dibutuhkan untuk mendukung upaya penanganan dan pencegahan kerawanan pangan dan gizi. Ketahanan pangan bersifat multidimensi sehingga melibatkan berbagai jenis indikator untuk menghasilkan nilai komposit ketahanan pangan. Penyusunan IKP berdasarkan pengukuran indeks global dengan berbagai penyesuaian metodologi berdasarkan ketersediaan data dan informasi pada masing-masing provinsi di Indonesia. IKP menggunakan indikator yang digunakan untuk penyusunan Food Security and Vulnerability Atlas (FSVA) 2020 yang dirancang oleh Kementerian Pertanian (Badan Ketahanan Pangan Kementerian Pertanian, 2020). Fokus perhitungan dalam mengukur kompleksitas ketahanan pangan terbagi menjadi 3 variabel utama seperti ketersediaan pangan, akses pangan dan pemanfaatan pangan dengan 9 indikator di dalamnya. Ketersediaan pangan telah tercapai pada saat jumlah pangan yang tersedia cukup secara konsisten untuk semua individu dalam suatu negara. Tabel 1 berikut ini adalah metrik terkait jenis satuan dari indikator aspek ketahanan pangan.

Tabel 1. Dimensi dan indikator ketahanan pangan

\begin{tabular}{|c|c|c|}
\hline Aspek & Indikator & Denominasi \\
\hline $\begin{array}{l}\text { Ketersediaan } \\
\text { Pangan }\end{array}$ & $\begin{array}{l}\text { Rasio konsumsi normatif perkapita terhadap } \\
\text { produksi pangan }\end{array}$ & Gram/perkapita/hari \\
\hline \multirow[t]{2}{*}{ Akses Pangan } & $\begin{array}{l}\text { Persentase penduduk yang hidup di bawah garis } \\
\text { kemiskinan } \\
\text { Persentase rumah tangga dengan proporsi } \\
\text { pengeluaran untuk lebih pangan lebih dari } 65 \text { persen } \\
\text { terhadap total pengeluaran }\end{array}$ & Persen \\
\hline & Persentase rumah tangga tanpa akses listrik & Persen \\
\hline Pemanfaatan & Rata-rata lama sekolah perempuan di atas 15 tahun & Tahun \\
\hline \multirow[t]{3}{*}{ Pangan } & $\begin{array}{l}\text { Persentase rumah tangga tanpa akses ke air bersih } \\
\text { Rasio jumlah penduduk per tenaga kesehatan } \\
\text { terhadap tingkat kepadatan }\end{array}$ & $\begin{array}{c}\text { Persen } \\
\text { Rasio }\end{array}$ \\
\hline & $\begin{array}{l}\text { Persentase balita dengan tinggi badan di bawah } \\
\text { standar (stunting) }\end{array}$ & Persen \\
\hline & Angka Kesakitan & Persen \\
\hline
\end{tabular}

Analisis data dalam penelitian ini mengimplementasikan data mining yang melibatkan proses-proses tertentu. Data mining melibatkan beberapa proses tertentu yang dinamakan Knowledge Discovery in Database (KDD). Proses tersebut di antaranya adalah data selection, data preprocessing (cleaning), data tranformation, data mining dan interpretation. Data selection adalah proses atau tahapan pertama, di mana data akan diseleksi dari sekumpulan data operasional sebelum dilakukan proses mining dilakukan. Pemilihan data akan menghasilkan himpunan atau set data yang memfokuskan pada subset variabel yang berhubungan 
dengan penelitian. Data pre-processing adalah proses pembersihan data atau proses penghapusan noise. Data pre-processing mencakup pembersihan duplikasi data, pembersihan typografi dan pembersihan tanda baca. Data transformation adalah proses untuk mentransformasikan data yang telah dibersihkan. Tujuan dari transformasi data adalah untuk menemukan fitur-fitur yang berguna untuk mempresentasikan data yang sesuai dengan fokus penelitian. Data mining adalah proses untuk mencari pola informasi dari sebuah data yang telah terpilih menggunakan metode tertentu. Interpretation adalah proses untuk menjabarkan pola-pola informasi yang dihasilkan oleh proses data mining yang telah dilakukan sebelumnya.

Penelitian ini menggunakan model data mining dengan metode clustering. Clustering adalah proses pengelompokan kumpulan data menjadi beberapa kelompok dimana objek dari suatu kelompok memiliki banyak kesamaan dan memiliki banyak perbedaan bila dibandingkan dengan kelompok lain. Tujuan clustering adalah agar objek-objek yang tergabung dalam satu kelompok merupakan objek-objek yang mirip (berhubungan) satu sama lain dan berbeda (tidak berhubungan) dengan kelompok lain. Penelitian ini menggunakan pendekatan non hierarki dengan metode $\mathrm{K}$ means, DBSCAN, Louvain Clustering dan Self Organizing Maps. Umumnya metodemetode clustering tidak memerlukan pelabelan data atau data terdahulu (unsupervised learning), sehingga langkah analisis yang dilakukan relevan untuk kondisi data yang fluktuatif.

\section{HASIL DAN PEMBAHASAN}

Pengolahan data yang digunakan dalam penelitian ini menggunakan software Orange Data Mining. Dataset yang digunakan adalah data yang terdiri dari nama provinsi beserta 3 variabel utamanya yaitu ketersediaan pangan, keterjangkauan pangan dan pemanfaatan pangan dengan masingmasing indikatornya. Analisis ini bertujuan untuk melihat jumlah cluster dan jumlah anggota tiap cluster dan nilai silhoutte coefficient yang telah dihasilkan dari masing-masing metode.

Tabel 2. Perbandingan jumlah klaster antar metode

\begin{tabular}{ccccccc}
\hline Metode & Cluster 1 & Cluster 2 & Cluster 3 & Cluster 4 & Cluster 5 & Cluster 6 \\
\hline K-means & 24 & 7 & 3 & - & - & - \\
DBSCAN & 33 & 1 & - & - & - & - \\
Louvain & 10 & 8 & 8 & 5 & 2 & 1 \\
Self Organizing Maps & 9 & 9 & 16 & - & - & -
\end{tabular}

Tabel 2 merepresentasikan hasil klasterisasi setiap metode beserta dengan jumlah provinsi di setiap klasternya. Pada metode K-means, hasil analisis dengan metode tersebut menghasilkan tiga klaster dengan 24 provinsi pada klaster 1,7 provinsi pada klaster 2 dan 3 provinsi pada klaster 3. Selanjutnya terdapat metode DBSCAN dengan jumlah klaster paling sedikit, yakni hanya 2 klaster. Klaster pertama dari DBSCAN menghasilkan 33 provinsi pada klaster 1 dan 1 provinsi pada klaster 2. Yang ketiga adalah metode louvain dengan jumlah klaster terbanyak, yakni 6 klaster. klaster 1 pada metode louvain menciptakan 10 provinsi, klaster 2 dan 3 dengan 8 provinsi, klaster 4 dengan 5 provinsi, klaster 5 dengan 2 provinsi dan klaster 6 dengan 1 provinsi. Yang terakhir adalah analisis klasterisasi dengan metode self organizing maps. Metode tersebut menghasilkkan tiga klaster, yakni 9 provinsi pada klaster 1 dan 2 dan 16 provinsi pada klaster 3 . 


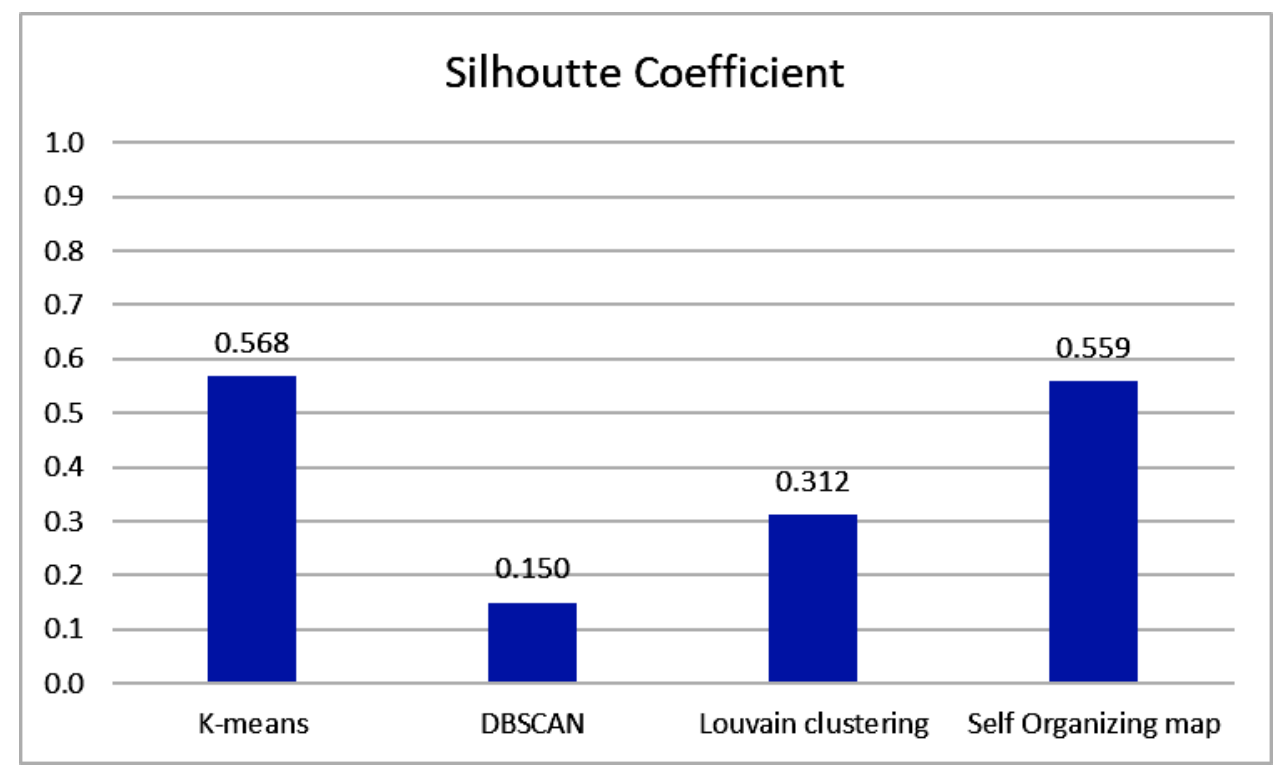

Gambar 1. Grafik perbandingan koefisien silhouette per metode

Setelah dilakukan pengujian secara keseluruhan, gambar 1 menunjukkan bahwa hasil metode K-means $(0,568)$ memiliki performa lebih baik dibanding DBSCAN (0,150), Louvain Clustering $(0,312)$ dan Self Organizig Maps $(0,559)$. Hal ini berdasarkan perbandingan nilai Silhouette Coefficient yang dihasilkan dari keempat metode tersebut. Nilai dari Silhouette Coefficient dari metode Kmeans lebih tinggi dibandingkan dengan metode DBSCAN, Louvain Clustering dan Self Organizing Maps. Metode K-means dan Louvain Clustering menggunakan inisialisasi cluster yang dilakukan secara acak pada saat pembangkitan cluster awal. Pembangkitan cluster awal tersebut ditujukan untuk memasukkan anggota IKP tingkat provinsi ke setiap cluster sesuai dengan jumlah cluster yang telah ditentukan sebelumnya. Sedangkan, metode DBSCAN menggunakan inisialisasi cluster setelah jumlah cluster telah ditentukan meskipun hasilnya unik, namun akurasi dari hasil tersebut tergolong kurang jika dibandingkan dengan metode K-means dan Louvain Clustering. Cluster yang dihasilkan oleh K-means lebih sedikit dari cluster yang dihasilkan oleh Louvain Clustering. Cluster K-means menghasilkan tiga cluster sedangkan Louvain clustering menghasilkan enam cluster. Setelah melakukan variasi penambahan jumlah cluster, ternyata variasi tersebut memberikan pengaruh terhadap nilai Silhouette Coefficient. Untuk nilai Silhouette Coefficient, nilainya akan semakin besar jika jumlah cluster semakin bertambah. Dan sebaliknya jika jumlah cluster semakin kecil, maka nilai dari Silhouette Coefficient akan semakin kecil. Artinya hampir disetiap cluster selalu dihasilkan anggota kelompok yang selalu mirip dengan anggota yang lainnya. Hasil pengujian menunjukkan bahwa metode $\mathrm{K}$ means menghasilkan tingkat akurasi yang paling baik. Metode ini menghasilkan tiga cluster seperti yang divisualisasikan pada gambar 2, tingkat rendah dengan warna merah untuk cluster pertama, tingkat sedang dengan warna kuning untuk cluster kedua dan tingkat tinggi dengan warna hijau untuk cluster ketiga. 


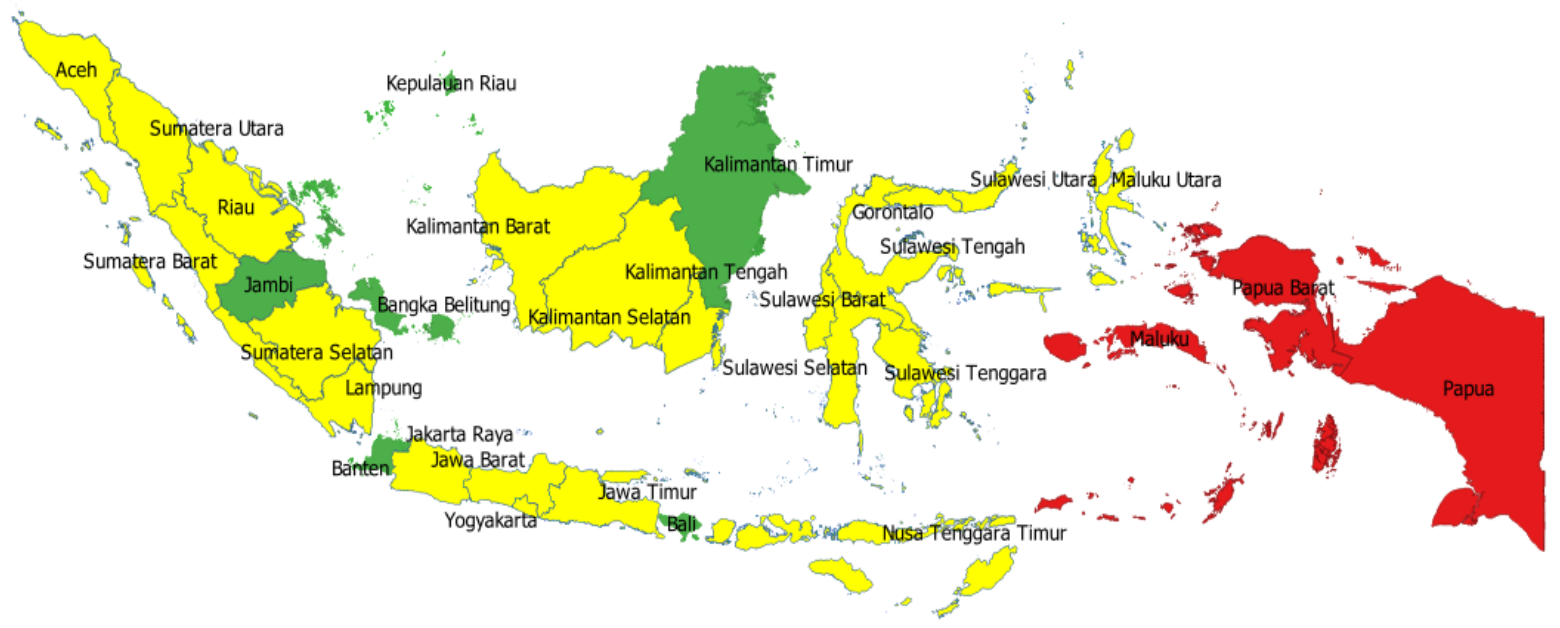

Gambar 2. Hasil pemetaan ketahanan pangan provinsi

Hasil dari penelitian analisis ketahanan pangan berdasarkan pada gambar 2 . menunjukkan terdapat tiga klaster, yakni rendah, sedang dan tinggi. Untuk klaster tinggi terdapat 7 provinsi, yaitu Provinsi Jambi, Bangka Belitung, Kepulauan Riau, DKI Jakarta, Banten, Bali dan Kalimantan Timur. Berikutnya terdapat 24 Provinsi dengan tingkat ketahanan pangan sedang, yakni Provinsi Aceh, Sumatra Utara, Sumatra Barat, Riau, Sumatra Selatan, Bengkulu, Lampung, Jawa Barat, Jawa Tengah, DIY, Jawa Timur, Nusa Tenggara Barat, Nusa Tenggara Timur, Kalimantan Barat, Kalimantan Tengah, Kalimantan Selatan, Kalimantan Utara, Sulawesi Utara, Sulawesi Tengah, Sulawesi Selatan, Sulawesi Tenggara, Gorontalo, Sulawesi Barat dan Maluku Utara serta 3 klaster provinsi dengan tingkat ketahanan rendah yakni Provinsi Maluku, Papua Barat dan Papua. Selanjutnya terdapat beberapa perbedaan hasil pemetaan ketahanan pangan pada penelitian ini dengan beberapa penelitian sebelumnya. Penelitian yang dilakukan oleh (Rahayu et al., 2019) yang menggunakan metode multivariate normal based clustering model dengan menggunakan 6 indikator, yakni rasio ketersediaan pangan terhadap konsumsi normatif perkapita, persentase masyarakat yang berada di bawah garis kemiskinan, produk domestik regional bruto perkapita, angka harapan hidup, rata-rata konsumsi kalori perkapita per hari dan rata-rata konsumsi protein perkapita perhari. Hasil dari penelitian tersebut memaparkan bahwa terdapat 10 provinsi dengan tingkat ketahanan pangan tinggi, 19 provinsi dengan tingkat ketahanan pangan sedang dan 5 provinsi dengan tingkat ketahanan pangan rendah. Selanjutnya terdapat penelitian terdahulu oleh (Syuryadi, Martianto, \& Sukandar, 2020) yang menggunakan metode pembobotan secara manual. Penelitian tersebut memaparkan terdapat 1 provinsi dengan tingkat ketahanan pangan tinggi, 27 provinsi dengan tingkat ketahanan pangan sedang dan 6 provinsi dengan tingkat ketahanan pangan rendah. Dengan demikian, penelitian-penelitian sebelumnya membuktikan bahwa indikator kerangka kerja dan metode yang digunakan berpengaruh terhadap hasil analisis ketahanan pangan.

Selanjutnya, kemunculan wabah pandemi Covid-19 yang secara tiba-tiba berdampak kepada banyak kerugian di berbagai sektor di dunia, salah satunya pada sosio-ekonomi dan ketahanan pangan. Nicola et al. (2020) memaparkan bahwa subsektor sosio ekonomi yang terdampak oleh Covid-19 adalah sektor pendidikan, keuangan, kesehatan, pariwisata, olahraga hingga teknologi. Banyak perusahaan yang mengalami ketidakstabilan kinerja memilih untuk mengurangi jumlah pegawai atau pemutusan hubungan kerja dengan tujuan efisiensi. Padahal hal tersebut membuat tingkat kemiskinan dan pengangguran turut 
meningkat. Di satu sisi, pengurang pegawai oleh perusahaan juga dinilai efektif dalam mengurangi beban operasionalitas. Dengan adanya pemutusan hubungan kerja yang berdampak pada tingkat kemiskinan dan pengangguran dapat memicu tingginya angka kriminalitas (Lin, 2008). Selain itu, pekerja yang terdampak oleh pemutusan kerja juga dimungkinkan berpengaruh pada kelaparan, kemiskinan hingga bunuh diri (Brand, 2015; Pérez- Escamilla, Cunningham, dan Moran, 2020). Namun juga terdapat perusahaan dengan kebijakan yang lebih memilih untuk memangkas upah pekerja dan mengimplementasikan sistem bekerja dari rumah. Dengan adanya kebijakan perusahaan yang lebih humanis tersebut, pegawai dapat terhindar dari risiko infeksi dan kemiskinan. Perusahaan yang mengimplementasikan kebijakan tersebut secara tidak langsung mengubah kebiasaan manusia. Sehingga dampak positif dari adanya wabah Covid-19, kebiasaan manusia menjadi sedikit berubah, yakni pemanfaatan teknologi secara masif, kepekaan terhadap kesehatan yang meningkat dan kesadaran dalam mitigasi akan bencana (Wolf et al., 2020). Namun, sektor pendidikan mengalami adanya ambiguitas dampak dari Covid-19. Hal tersebut dibuktikan dengan adanya sistem pembelajaran secara daring di seluruh dunia. Pembelajaran daring dewasa ini memiliki pengaruh terhadap kepuasan, komptensi, keaktifan dan prestasi siswa (Hsu, Wang dan Levesque-Bristol, 2019). Namun validitas hasil siswa tersebut masih perlu dipertanyakan mengingat tidak adanya interaksi sosial secara langsung antar siswa. Sehingga hal ini menjadi tantangan tersendiri untuk subsektor pendidikan.

Selain berdampak pada sektor sosioekonomi, pandemi Covid-19 juga berdampak pada ketahanan pangan nasional. Pandemi Covid-19 ini menimbulkan ancaman kelangkaan pangan akibat penurunan produksi pangan. Dampak tersebut merupakan efek domino dari turunnya permintaan pangan setelah adanya anomali panic buying. Sehingga dapat dikatakan bahwa adanya sebuah wabah penyakit akan berdampak pada kelaparan dan malnutrisi ditinjau dari sisi kelangkaan pangan (Burgui, 2020). Disisi lain, intervensi kelangkaan pangan tidak hanya secara langsung disebabkan oleh Pandemi Covid-19, namun juga dipengaruhi oleh beberapa faktor teknis lainnya seperti rantai pasok, harga pangan, permintaan pangan, pendapatan individu dan jenis kelompok (Siche, 2020). Pada permasalahan rantai pasok pangan, pada dasarnya berawal dari semakin banyak pihak yang terlibat dalam pasokan, maka juga semakin banyak pihak yang terlibat atau berpotensi terinfeksi karena interaksi (Rizou et al., 2020). Hal tersebut disebabkan oleh karantina wilayah yang membatasi kendaraan dari luar untuk memasuki sebuah kota. Sehingga, keterbatasan stok pangan menjadi berkurang dan menyebabkan kelangkaan dan meningkatnya harga pangan (Benton, 2020). Selanjutnya adalah dampak Covid-19 terhadap permasalahan permintaan pangan dan pendapatan individu. Permintaan makanan telah menurun karena ketidakpastian dan pengurangan kapasitas pengeluaran masyarakat dan situasi dapat memburuk jika pandemi berlanjut untuk waktu yang lama, karena berkurangnya pendapatan dan hilangnya pekerjaan (Food and Agriculture Organization, 2020). Dengan demikian, permasalahan permintaan pangan dan pendapatan individu sangat berkorelasi. Selanjutnya, jenis kelompok masyarakat juga menjadi sebuah permasalahan, terutama pada kelompok masyarakat petani kecil, anak-anak dengan penderita malnutrisi dan masyarakat yang mengalami kelaparan (Siche, 2020). Hal tersebut dikarenakan tidak adanya akses dan mata pencaharian untuk pangan dalam kondisi pandemi Covid-19 ini. Sehingga permasalahan dari dampak Covid-19 pada sektor ketahanan pangan merupakan salah satu permasalahan yang cukup kompleks.

Dalam menanggulangi dampak Covid19 terhadap ketahanan pangan, maka setiap provinsi harus menerapkan kebijakan lokal terdesentralisasi yang sesuai dengan kondisi masyarakat masing-masing mengingat 
adanya perbedaan tingkat ketahanan pangan di setiap daerah. Sistem pangan memiliki peran penting dalam menyelesaikan problematika terkait kelaparan di masyarakat dan menjamin sustainabilitas konsumsi dan produksi (Galanakis, 2020). Dengan adanya tingkat ketahanan pangan yang berbeda di setiap provinsi, maka kebijakan terkait dengan sistem pangan juga berbeda. Pada penelitian ini mengklasterisasi tingkat ketahanan pangan provinsi menjadi tiga, yaitu tinggi, sedang dan rendah. Pada dasarnya, provinsi yang memiliki tingkat ketahanan pangan yang rendah menjadi prioritas utama untuk ditangani. Meskipun setiap provinsi mengalami turbulensi pangan karena adanya dampak nyata dari Covid-19, provinsi dengan tingkat ketahanan rendah akan terdampak paling masif. Sehingga kesiapan pangan termasuk ketersediaan, akses dan pemanfaatan provinsi tersebut wajib untuk ditingkatkan. Menurut hasil klasterisasi, provinsi yang memiliki tingkat ketahanan pangan rendah adalah Provinsi Maluku, Papua Barat dan Papua. Hal ini disebabkan oleh faktor geografis dan tidak meratanya sumber daya di Indonesia bagian timur. Jalur rantai pasok dan medan yang sulit ditempuh membuat pasokan makanan sulit untuk didistribusikan. Selain itu, aspek kemandirian dalam memanfaatkan serta mengelola pangan yang rendah membuat provinsi-provinsi dengan tingkat ketahanan pangan yang rendah menjadi rawan akan terjadinya kelaparan. Sehingga stabilitas pasokan ketersediaan pangan perlu untuk diinisiasi lebih dalam. Selanjutnya, provinsiprovinsi dengan tingkat ketahanan pangan sedang dan tinggi dinilai dapat bertahan dalam kondisi pandemi Covid-19. Namun juga terdapat beberapa tantangan seperti mitigasi risiko panic buying dan stabilitas pangan.

Dalam penanganan dampak Covid-19 terhadap ketahanan pangan, strategi dan resolusi yang direncanakan dan akan diimplementasikan memiliki metode yang berbeda-beda berdasarkan setiap kondisi provinsi. Strategi dan resolusi terkait dengan kebijakan ketahanan pangan dalam menghadapi pandemi Covid-19 pada penelitian ini disusun berdasarkan beberapa penelitian sebelumnya (Ferjani, Mann dan Zimmermann, 2018; Mulwa dan Visser, 2020; Suryana, 2014; Waha et al., 2018). Perbedaan kondisi yang berbeda-beda di setiap provinsi membuat harus adanya diferensiasi strategi. Selain itu, strategi yang diusulkan dikelompokkan berdasarkan aspek-aspek ketahanan pangan, yakni ketersediaan pangan, akses pangan dan pemanfaatan pangan. Sehingga strategi yang diusulkan lebih fokus dan terperinci terhadap tingkat ketahanan provinsi dan aspek ketahanan pangan. Tabel 3 berikut ini adalah usulan strategi ketahanan pangan yang relevan terhadap tingkat kategori ketahanan di setiap provinsi:

Tabel 3. Usulan strategi ketahanan pangan nasional dalam menghadapi covid-19

\begin{tabular}{|c|c|c|c|}
\hline & Ketersediaan & Akses & Pemanfaatan \\
\hline 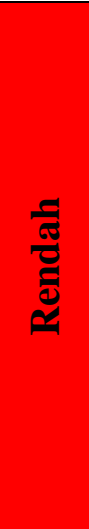 & 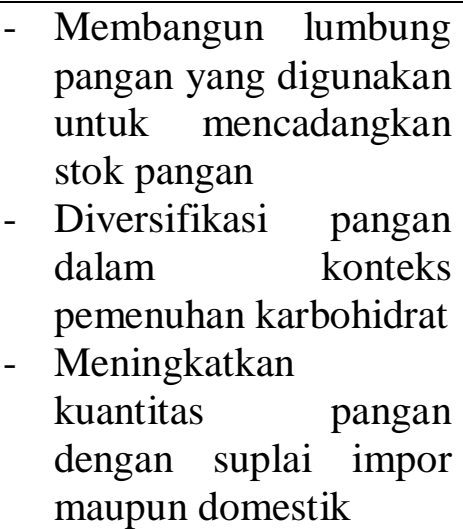 & 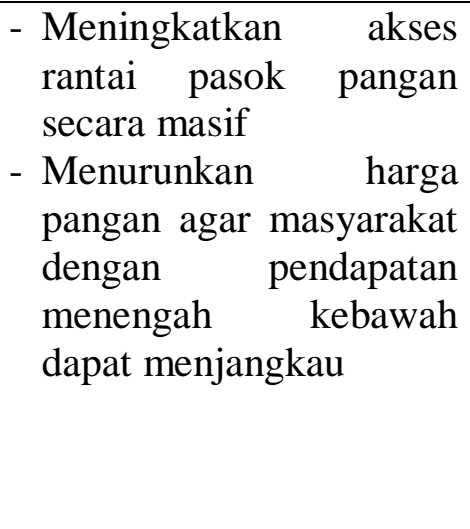 & 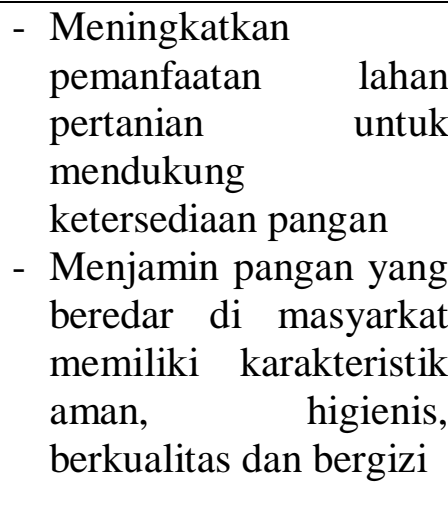 \\
\hline
\end{tabular}




\begin{tabular}{|c|c|c|c|}
\hline 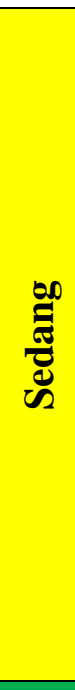 & $\begin{array}{l}\text { - Membangun lumbung } \\
\text { pangan yang digunakan } \\
\text { untuk mencadangkan } \\
\text { stok pangan } \\
\text { - Meningkatkan kuantitas } \\
\text { supply pangan dari } \\
\text { domestik } \\
\text { - menghimpun usaha tani } \\
\text { berskala kecil untuk } \\
\text { diintegrasikan agar } \\
\text { mencapai skala nasional }\end{array}$ & $\begin{array}{l}\text { - Menjaga stabilitas harga } \\
\text { dan ketersediaan pangan } \\
\text { - Memperkuat dan } \\
\text { memfasilitasi } \\
\text { pengembangan } \\
\text { pemasaran dan } \\
\text { perdagangan pangan } \\
\text { yang efisien serta } \\
\text { pengembangan pasar } \\
\text { pangan di perdesaan } \\
\text { - Menjaga stabilitas rantai } \\
\text { pasok pangan dengan } \\
\text { memperhatikan protokol } \\
\text { kesehatan }\end{array}$ & $\begin{array}{l}\text { - Pemenuhan konsumsi } \\
\text { pangan yang beragam } \\
\text { bergizi seimbang dan } \\
\text { aman (B2SA) } \\
\text { - Memperbaiki status } \\
\text { gizi masyarakat melalui } \\
\text { pengayaan atau } \\
\text { fortifikasi untuk zat } \\
\text { gizi tertentu pada } \\
\text { pangan yang } \\
\text { dikonsumsi sebagian } \\
\text { besar masyarakat, } \\
\text { seperti beras, minyak } \\
\text { goreng, dan garam }\end{array}$ \\
\hline 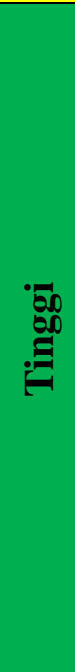 & $\begin{array}{l}\text { - Membangun lumbung } \\
\text { pangan yang digunakan } \\
\text { untuk mencadangkan } \\
\text { stok pangan } \\
\text { - Menjamin kuantitas } \\
\text { pangan yang beredar di } \\
\text { masyarakat agar tidak } \\
\text { terjadi kelangkaan }\end{array}$ & $\begin{array}{l}\text { - Menjaga stabilitas harga } \\
\text { dan ketersediaan pangan } \\
\text { - Menjaga stabilitas rantai } \\
\text { pasok pangan dengan } \\
\text { memperhatikan protokol } \\
\text { kesehatan }\end{array}$ & $\begin{array}{l}\text { - Pemenuhan konsumsi } \\
\text { pangan yang beragam } \\
\text { bergizi seimbang dan } \\
\text { aman (B2SA) } \\
\text { - Memperbaiki status } \\
\text { gizi masyarakat melalui } \\
\text { pengayaan atau } \\
\text { fortifikasi untuk zat } \\
\text { gizi tertentu pada } \\
\text { pangan yang } \\
\text { dikonsumsi sebagian } \\
\text { besar masyarakat, } \\
\text { seperti beras, minyak } \\
\text { goreng, dan garam }\end{array}$ \\
\hline
\end{tabular}

Tabel 3 menjelaskan usulan strategi ketahanan pangan untuk setiap provinsi berdasarkan tingkat ketahanan pangan masing-masing. Usulan strategi ketahanan pangan dikelompokkan berdasarkan variabel yang digunakan oleh Kementerian Pertanian, yakni ketersediaan pangan, akses pangan dan pemanfaatan pangan. Hal tersebut dilakukan agar mendapatkan strategi yang akurat. Pada usulan strategi terkait ketersediaan pangan dengan tingkat ketahanan pangan rendah, provinsi terkait disarankan untuk fokus menghimbau masyarakat agar memilih jenis karbohidrat lain serta meningkatkan suplai pangan dari impor maupun lokal. Sedangkan pada provinsi dengan tingkat ketahanan pangan sedang dan tinggi, provinsi diharapkan untuk menjaga stabilitas ketersediaan pangan dengan cara menghimpun usaha tani berskala kecil maupun nasional tanpa melibatkan produk impor. Pada variabel akses pangan provinsi dengan tingkat ketahanan pangan rendah, provinsi diharapkan untuk meningkatkan rantai pasok pangan secara masif dan menurunkan harga pangan. Usulan strategi ini merupakan langkah agresif untuk ditempuh karena memerlukan kebijakan yang darurat. Sehingga pemerintah perlu mencadangkan anggaran darurat di masa pandemi Covid-19 ini. Pada provinsi dengan tingkat ketahanan pangan sedang dan tinggi, kendala terkait dengan akses pangan tidak menjadi sebuah problematika yang signifikan. Sehingga provinsi dengan tingkat ketahanan pangan sedang dan tinggi hanya perlu menjaga stabilitas pangan seperti biasa dengan menerapkan protokol kesehatan yang diwajibkan oleh pemerintah pusat. Pada variabel pemanfaatan pangan pada provinsi dengan tingkat ketahanan pangan rendah, 
provinsi diusulkan agar memanfaatkan lahan yang ada untuk ditanami bahan makanan pokok sebagai langkah darurat serta melakukan uji kualitas pangan yang beredar di masyarakat. Pada provinsi dengan tingkat ketahanan pangan sedang dan tinggi, fokus strategi yang diusulkan adalah peningkatan dan pemenuhan gizi di masyarakat agar dapat meningkatkan imunitas tubuh selama masa pandemi Covid-19.

\section{KESIMPULAN}

Penelitian ini memberikan analisis terkait dengan pengelompokan ketahanan pangan setiap provinsi yang ada di Indonesia serta memberikan perbandingan terkait akurasi metode klastrerisasi. Metode klasterisasi yang digunakan untuk menganalisis pada penelitian ini adalah metode K-Means, DBSCAN, Louvain Clustering dan Self Organizing Maps. Hasil dari penelitian ini menunjukkan bahwa metode $\mathrm{K}$-means memiliki nilai silhouette coefficient yang paling tinggi $(0,568)$ dibandingkan dengan metode lainnya seperti DBSCAN (0,150), Louvain Clustering $(0,312)$ dan Self Organizing Maps $(0,559)$. Sehingga hasil klasterisasi dengan menggunakan metode K-means dipilih untuk merepresentasikan indeks ketahanan pangan nasional berdasarkan tingkat provinsi. Selanjutnya, hasil analisis memaparkan bahwa indeks ketahanan pangan nasional dibagi menjadi tiga klsater, yakni tinggi, sedang dan rendah dimana terdapat 7 provinsi dengan indeks ketahanan yang tinggi, 24 provinsi dengan indeks ketahanan sedang dan 3 provinsi dengan indeks ketahanan rendah. Penelitian ini turut memberikan implikasi dan rekomendasi kebijakan berdasarkan tingkat ketahanan pangan dan aspek pengukuran ketahanan pangan untuk setiap kondisi provinsi dalam menghadapi pandemi Covid-19. Hasil rekomendasi kebijakan yang diusulkan pada tabel 2 disusun berdasarkan observasi penelitian sebelumnya. Sehingga rekomendasi tersebut diharapkan dapat direalisasikan dalam kebijakan ketahanan pangan yang nyata untuk menghadapi pandemi Covid-19. Namun penelitian ini juga memiliki beberapa keterbatasan, seperti hasil analisis tingkat ketahanan pangan hanya dikelompokkan berdasarkan level provinsi. Sehingga terdapat adanya perbedaan kondisi di lapangan mengingat adanya perbedaan tingkat ketahanan pangan di level kabupaten bahkan di tingkat desa. Selain itu, analisis pengelompokan ketahanan pangan pada penelitian ini terbatas pada metode unsupervised learning. Dengan demikian, pengembangan penelitian selanjutnya diharapkan dapat menganalisis tingkat ketahanan pada level kabupaten dan desa dengan menggunakan metode supervised learning.

\section{DAFTAR PUSTAKA}

Adeniyi, D. A., \& Dinbabo, M. F. (2020). Efficiency, food security and differentiation in small-scale irrigation agriculture: Evidence from North West Nigeria. Cogent Social Sciences, 6(1), $1-19$.

https://doi.org/10.1080/23311886.2020 .1749508

Badan Ketahanan Pangan Kementerian Pertanian. (2020). Panduan fsva provinsi 2020.

Benton, T. G. (2020). Covid-19 and disruptions to food systems. Agriculture and Human Values. https://doi.org/10.1007/s10460-02010081-1

Brand, J. E. (2015). The far-reaching impact of job loss and unemployment. Annual Review of Sociology, 41(1), 359-375. https://doi.org/10.1146/annurev-soc071913-043237

Burgui, D. (2020). Oronavirus: how action against hunger is responding to the pandemic.

Ferjani, A., Mann, S., \& Zimmermann, A. (2018). An evaluation of Swiss agriculture's contribution to food security with decision support system for food security strategy. British Food Journal, 120(9),

2116-2128. 
https://doi.org/10.1108/BFJ-12-20170709

Food and Agriculture Organization. (2008). The State of Food Insecurity in the World 2008. Rome: Food and Agriculture Organization of the United Nations.

Food and Agriculture Organization. (2020). FAO Director-General urges G20 to ensure that food value chains are not disrupted during covid-19 pandemic. Retrieved from http://www.fao.org/news/story/en/item /1268254/ico

Galanakis, C. M. (2020). The Food systems in the era of the coronavirus (covid-19) Pandemic Crisis. Foods, 9(4), 523. https://doi.org/10.3390/foods9040523

Godfray, H. C. J., \& Garnett, T. (2014). Food security and sustainable intensification.

Philosophical Transactions of the Royal Society B: Biological Sciences, 369(1639), 20120273.

https://doi.org/10.1098/rstb.2012.0273

Headey, D. D., \& Martin, W. J. (2016). The Impact of food prices on poverty and food security. Annual Review of Resource Economics, 8(1), 329-351. https://doi.org/10.1146/annurevresource-100815-095303

Hsu, H.-C. K., Wang, C. V., \& LevesqueBristol, C. (2019). Reexamining the impact of self-determination theory on learning outcomes in the online learning environment. Education and Information Technologies, 24(3), 2159-2174.

https://doi.org/10.1007/s10639-01909863-w

King, T., Cole, M., Farber, J. M., Eisenbrand, G., Zabaras, D., Fox, E. M., \& Hill, J. P. (2017). Food safety for food security: Relationship between global megatrends and developments in food safety. Trends in Food Science \& Technology, 68, 160175.

https://doi.org/10.1016/j.tifs.2017.08.0 14
Lin, M.-J. (2008). Does unemployment increase crime? journal of human resources, 43(2), 413-436. https://doi.org/10.3368/jhr.43.2.413

Mulwa, C. K., \& Visser, M. (2020). Farm diversification as an adaptation strategy to climatic shocks and implications for food security in northern Namibia. World Development, $\quad 129, \quad 104906$. https://doi.org/10.1016/j.worlddev.202 0.104906

Nicola, M., Alsafi, Z., Sohrabi, C., Kerwan, A., Al-Jabir, A., Iosifidis, C., ... Agha, R. (2020). The socio-economic implications of the coronavirus pandemic (covid-19): A review. International Journal of Surgery, 78, 185-193.

https://doi.org/10.1016/j.ijsu.2020.04.0 18

Pérez- Escamilla, R., Cunningham, K., \& Moran, V. H. (2020). Covid-19 and maternal and child food and nutrition insecurity: a complex syndemic. Maternal \& Child Nutrition, 16(3), 811. https://doi.org/10.1111/mcn.13036

Pinstrup-Andersen, P. (2009). Food security: definition and measurement. Food Security, $\quad 1(1), \quad 5-7$. https://doi.org/10.1007/s12571-0080002-y

Rahayu, R. S., Purwaningsih, Y., \& Daerobi, A. (2019). Mapping Of Provincial Food Security In Indonesia Using Based Clustering Model. Jurnal Ekonomi Pembangunan: Kajian Masalah Ekonomi Dan Pembangunan, 20(1), 69-79. https://doi.org/10.23917/jep.v20i1.709 6

Rizou, M., Galanakis, I. M., Aldawoud, T. M. S., \& Galanakis, C. M. (2020). Safety of foods, food supply chain and environment within the covid-19 pandemic. Trends in Food Science \& Technology. https://doi.org/10.1016/j.tifs.2020.06.0 08

Roy, D., Tripathy, S., Kar, S. K., Sharma, 
N., Verma, S. K., \& Kaushal, V. (2020). Study of knowledge, attitude, anxiety \&amp; perceived mental healthcare need in Indian population during covid-19 pandemic. Asian Journal of Psychiatry, 51, 102083. https://doi.org/10.1016/j.ajp.2020.1020 83

Schmidhuber, J., \& Tubiello, F. N. (2007). Global food security under climate change. Proceedings of the National Academy of Sciences, 104(50), 1970319708.

https://doi.org/10.1073/pnas.07019761 04

Siche, R. (2020). What is the impact of covid-19 disease on agriculture? Scientia Agropecuaria, 11(1), 3-6. https://doi.org/10.17268/sci.agropecu.2 020.01 .00

Sudirman, Windarto, A. P., \& Wanto, A. (2018). Data mining tools | rapidminer: $\mathrm{K}$-means method on clustering of rice crops by province as efforts to stabilize food crops in Indonesia. IOP Conference Series: Materials Science and Engineering, 420, 012089. https://doi.org/10.1088/1757899X/420/1/012089

Suryana, A. (2014). Menuju ketahanan pangan indonesia berkelanjutan 2025: tantangan dan penanganannya. Forum Penelitian Agro Ekonomi, 32(2), 123. https://doi.org/10.21082/fae.v32n2.201 4.123-135
Syuryadi, N., Martianto, D., \& Sukandar, D. (2020). Pengembangan metode evaluasi komitmen ketahanan pangan dan gizi pemerintah daerah provinsi di Indonesia. Amerta Nutrition, 4(2), 140-146.

https://doi.org/10.20473/amnt.v4i2.202 $0.140-146$

The Lancet. (2013). Maternal and child nutrition: Executive Summary of The Lancet Maternal and Child Nutrition Series.

Waha, K., van Wijk, M. T., Fritz, S., See, L., Thornton, P. K., Wichern, J., \& Herrero, M. (2018). Agricultural diversification as an important strategy for achieving food security in Africa. Global Change Biology, 24(8), 33903400. https://doi.org/10.1111/gcb.14158

Wolf, L. J., Haddock, G., Manstead, A. S. R., \& Maio, G. R. (2020). The importance of (shared) human values for containing the covid-19 pandemic. British Journal of Social Psychology, bjso.12401.

https://doi.org/10.1111/bjso.12401 